\title{
The restitution of illicitly exported cultural properties: Recent Italian cases
}

\author{
Tullio Scovazzi
}

For citation: Scovazzi, Tullio. 2020. The restitution of illicitly exported cultural properties: Recent Italian cases. Pravovedenie 64 (1): 156-163. https://doi.org/10.21638/spbu25.2020.112

\begin{abstract}
The question of restitution of removed cultural properties to which existing treaties do not apply for chronological or other reasons, is far from being settled under customary international law. It seems that an evolutionary trend is developing in present customary international law according to which claims related to the movements of cultural properties should be addressed in order to achieve an equitable solution, taking into account all relevant circumstances. These circumstances include: factors surrounding the removal of the cultural property from the state of origin, in particular the legality of the removal under the law of the state of origin or the substantive injustice of the removal; the importance of the cultural property for the state of origin, including its emblematic character; harm to the integrity of the cultural context from which the cultural property was removed; the amount of time since the cultural property was removed from the state of origin; the appreciation for and the care used to preserve the cultural property in the state of destination; the state of origin's commitment to care for the preservation of the cultural property if it is returned to it. Agreements between the Italian Ministry of Cultural Properties and activities by American museums are aimed at resolving disputes over the return of cultural properties in order to reach an equitable solution taking into account all relevant circumstances. This objective should govern relations between states of origin and states of destination of cultural properties, and should also be shared, if this is the case, also by nonstate entities concerned. Non-adversarial procedures, such as negotiation, mediation or conciliation, should be put in place to achieve the objective.
\end{abstract}

Keywords: restitution, removed cultural properties, customary international law, non-adversarial procedures, mediation, conciliation, illicitly exported cultural properties, Italian cases.

\section{The Euphronios krater}

The story of the Euphronios krater (a big vase used to mix wine and water) well documents the gravity of the looting of archaeological sites and the consequent international trafficking of cultural properties that affected Italy in the last decades ${ }^{1}$. It also shows how notable to address the question of the restitution of illicitly exported cultural properties is the practice developed by the Italian Ministry for Cultural Properties and Activities (hereinafter: the Ministry) to conclude agreements with foreign museums².

Tullio Scovazzi - Professor of International Law, University of Milano-Bicocca, 1, Piazza dell'Ateneo Nuovo, Milan, 20126, Italy; tullio.scovazzi@unimib.it

1 On the looting see: Watson P., Todeschini C. The Medici Conspiracy - The Illicit Journey of Looted Antiquities from Italy's Tomb Raiders to the World's Greatest Museums: New York: Public Affairs, 2006; Felch J., Frammolino R. Chasing Aphrodite - The Hunt for Looted Antiquities at the Worlds' Richest Museum. Boston: Houghton Mifflin Harcourt, 2011.

${ }^{2}$ See: Fiorilli M. Cultural Properties and International Agreements // International Meeting on Illicit Traffic of Cultural Property / ed. by J. Papadopoulos. Rome: Gangemi Editore, 2010. P. 161; Scovazzi T. Analisi e significato della pratica italiana // La restituzione dei beni culturali rimossi con particolare riguardo alla pratica italiana / ed. by A. L. Scovazzi. Milan: Giuffre Editore, 2014. P. 3.

() St. Petersburg State University, 2021 
After having been manufactured by Euxitheos, the vase was painted and signed by the Athenian artist Euphronios (active between 520 and 470 B. C.), one of the three great masters of red-figure vases. It is one of the best Attic vases, the only complete among the twenty-seven known as painted by Euphronios. The obverse side represents the god Hermes who supervises the transport by Hypnos (Sleep) and Thanatos (Death) of the corpse of the Trojan hero Sarpedon, killed in battle. The reverse side represents warriors arming themselves. At the time of Euphronios, the most valuable Greek vases were manufactured and painted in Athens and then exported to Central Italy where the Etruscans bought them for high prices.

In 1972 the Euphronios krater appeared for the first time in the collections of the Metropolitan Museum of Art of New York (hereinafter: the Metropolitan Museum). It was bought in exchange for 1000000 US \$ and several ancient Greek coins. In an interview given on 12 November 1972, the director of the Museum, Mr. Thomas Hoving, provided quite vague information about the provenance of the property:

We got it from a dealer who was the agent for a person who has had this in the family collection since about the First World War and we don't talk about the name of these people because they have other things that we might want to buy in the future.

$\langle\ldots\rangle$ we bought it from somebody who happened to be in the country of Switzerland, who was acting as the agent for somebody who was even in another country whose family had it since around the First World War and that goes back a nice long time ${ }^{3}$.

The story became even less credible when Mr. Dietrich von Bothmer, the curator of Greek and Roman art at the Museum, disclosed that the previous owners of the property were the members of an Armenian family who because of unfortunate events were forced to leave their home in Lebanon and emigrate to Australia 4 .

After some time, the truth was unveiled following an unexpected event. An Italian antique dealer died in a car accident. In his pocket the police found a piece a paper with the names of several people involved in the trafficking of illicitly excavated archaeological properties. The Italian authorities concentrated their interest on Mr. Giacomo Medici, another Italian antiquarian. In cooperation with the Swiss police, they inspected a threeroomed warehouse held by Mr. Medici at the free-port of the Geneva airport. What they found was astonishing. In the warehouse were kept about 3000 artifacts, often of very high quality, most of them illegally excavated in Italy $^{5}$, together with a detailed archive that shed light on a chain of people involved at different levels in the illegal trafficking, export and sale of archaeological properties: diggers (so-called tombaroli, in Italian), middlemen, traders, restorers, experts, European and American museum curators and collectors. Pictures were also found that provided useful evidence about the relevant facts. In the case of the Euphronios krater, the pictures documented the vase when found in a clandestine excavation $^{6}$, the vase during the restoration and the vase exhibited at the Museum, with Mr. Medici and Mr. Robert Hecht (the American antiquarian who bought the vase from Mr. Medici and sold it to the Museum) smiling next to it. Besides recovering the items deposited in the warehouse, the Italian police and prosecutors were able to reconstruct the

3 The interview is published in: Meyer K. The Plundered Past. New York: Arts Book Society, 1973. P. 302.

4 Ibid. P. 93.

5 Including frescos detached in the area of Pompei from a villa clandestinely excavated and irreparably damaged by the looters.

6 The looters used the polaroid technique, also to avoid the risk of entrusting a photographer with the printing of the pictures. The polaroid technique, which was developed in the United States after World War II and introduced in Europe some years later, provides sure evidence that the excavations were made after the enactment (1909) of the Italian legislation that prohibited unauthorized archaeological excavations.

Правоведение. 2020. Т. 64 , № 1 
whereabouts of many archaeological properties that had already been sold to museums and collectors ${ }^{7}$.

It was finally proved that the Euphronios krater had been clandestinely excavated in 1971 at Cerveteri, in the core of the area inhabited in ancient times by the Etruscans ${ }^{8}$. It was illicitly ${ }^{9}$ exported from Italy to Switzerland and, after a number of transfers, sold to the Museum by Mr. Hecht, who imported it legally ${ }^{10}$ in the United States ${ }^{11}$. It seems that the customs officer at the airport in New York made a pertinent comment when he asked to inspect the box that Mr. Hecht brought and saw the vase: "I don't know anything about Greek art, but you've really got something beautiful here"12.

After the discovery of its real provenance, the problem for the Italian authorities was how to get the vase back.

\section{The Agreements}

The problem was finally solved by the conclusion of an agreement between the Ministry and the foreign museum concerned. Agreements of this kind have been concluded subsequently also with other foreign cultural institutions, such as the Museum of Fine Arts di Boston, the Princeton University Art Museum, the John Paul Getty Museum of Los Angeles, the Cleveland Museum of Art and the Dallas Museum of Art ${ }^{13}$. While usually called "agreements", this kind of instruments cannot be considered as international treaties, belonging to the category of contracts between States and foreign nationals ${ }^{14}$.

The agreements allow the State of origin to overcome the obstacles posed the uncertain outcome of litigation before a foreign court on the ownership of the claimed properties. They also allow the foreign museums to preserve their reputation as truthful cultural institutions that do not encourage the pillage of the heritage of foreign countries and do participate in the fight against the destruction of cultural contexts and the illicit traffic resulting therefrom. Both parties agree on the strengthening of their relationship through future cooperative activities, including loans granted by ltaly of archaeological properties of high value.

While the text of most agreements is kept confidential, an exception is the agreement signed on 21 February 2006 by the Ministry and the Commission for Cultural Properties of the Region of Sicily ${ }^{15}$, on the one hand, and the Metropolitan Museum, on the other.

7 Unfortunately, it was not possible to locate a rare Etruscan Sarcophagus with Spouses which appears in one of the pictures seized. Was it sold to a private collector who keeps it hidden?

8 See: Rizzo M. A. Gli scavi clandestini a Cerveteri // Ministero per I Beni Culturale Ambientali. Bollettino d'Arte. 1995. No. 89-90. Annex. P. 15.

9 Illicitly, according to Italian law.

10 Legally, according to United States law.

11 Today such an import would be illicit also according to United States law, because of the Agreement between Italy and the United States concerning the imposition of import restrictions on categories of archaeological material representing the pre-classical, classical and imperial Roman periods of Italy (Washington, 19 January 2001; renewed in 2006 and 2011).

12 See: Meyer K. The Plundered Past. P. 91.

13 In 2012 an agreement was concluded with a Japanese institution, the Tokyo Fuji Art Museum. It provides for the return, under certain conditions, of the Tavola Doria, an anonimous painting of the $16^{\text {th }}$ century reproducing a portion of The Battle of Anghiari, a lost fresco by Leonardo da Vinci on a wall of Palazzo Vecchio in Florence.

14 This type of legal instruments, which has an important background in the field of exploitation of natural resources (for example, concessions to foreign companies for oil exploration and exploitation), are used here to pursue a rather different purpose.

15 Under the Italian constitutional system, Sicily is the only region entitled to exercise an exclusive competence as regards the cultural properties existing in the region. 
In the premise of the agreement, the Ministry states that the Italian archaeological heritage "is the source of the national collective memory and a resource for historical and scientific research". It also recalls some basic aspects of the Italian legislation on cultural properties, in particular that:

- the archaeological heritage includes the structures, constructions, architectural complex, archaeological sites, movable objects and monuments of other types as well as their contexts, whether they are located underground, on the surface or under water (preambular para. B);

- to preserve the archaeological heritage and guarantee the scientific character of archaeological research and exploration operations, Italian law sets forth procedures for the authorization and control of excavations and archaeological activities to prevent all illegal excavations or theft of items of the archaeological heritage and to ensure that all archaeological excavations and explorations are undertaken in a scientific manner by qualified and specially trained personnel, with the provision that non-destructive exploration methods will be used whenever possible (preambular para. C).

In fact, under the Italian Legislative Decree 22 January 2004, No. 42 (Code of Cultural Properties and Landscape), all cultural properties found by anyone in any way in the subsoil or on the seabed belong to the State demesne, if immovable, or to the inalienable patrimony of the State, if movable (Art. 91, para. 1). The finder is entitled to a reward which cannot exceed one-fourth of the value of the properties found. A reward is also granted to the owner of the immovable property where the find has been made and to the holder of a concession for research ${ }^{16}$. The reward may be paid either in money or through the cession of part of the properties found (Art. 92, para. 4) ${ }^{17}$. A special procedure, as specified in Art. 93, applies in order to determine the amount of the reward. Legislation based on similar principles has been in force in Italy since 1909 (Law 20 June 1909, No. 364; Law 1st June 1939, No. 1089; Legislative Decree 29 October 1999, No. 490).

In the premise of the agreement it is also stated that the Metropolitan Museum:

- believes that the artistic achievements of all civilizations should be preserved and represented in art museums, which, uniquely, offer the public the opportunity to encounter works of art directly, in the context of their own and other cultures, and where these works may educate, inspire and be enjoyed by all. The interests of the public are served by art museums around the world working to preserve and interpret our shared cultural heritage (preambular para. F);

$-\langle\ldots\rangle$ deplores the illicit and unscientific excavation of archaeological materials and ancient art from archaeological sites, the destruction or defacing of ancient monuments, and the theft of works of art from individuals, museums, or other repositories (preambular para. G);

$-<\ldots>$ is committed to the responsible acquisition of archaeological materials and ancient art according to the principle that all collecting be done with the highest criteria of ethical and professional practice (preambular para. $\mathrm{H}$ ).

The first objective of the agreement is the return of a number of archaeological items that the Ministry has requested, affirming that they "were illegally excavated in Italian territory and sold clandestinely in and outside the Italian territory" (preambular para. E). The Metropolitan Museum, "rejecting any accusation that it had knowledge of the alleged illegal provenance in Italian territory of the assets claimed by Italy, has resolved to transfer the requested items in the context of this Agreement" (preambular para. I). The transfer does not constitute an acknowledgment on the part of the Metropolitan Museum of any

16 No reward is due to the finder if he has entered into an immovable property without the consent of the owner (Art. 92, para. 3).

17 A tax credit of value corresponding to the reward can be granted on request to those who are entitled to the reward. 
type of civil, administrative or criminal liability for the original acquisition or holding of the requested items. The Ministry and the Region Sicily waive any legal action in relation to the returned items.

The items in question magnificently document the spreading of ancient Greek civilization in Southern Italy. They are the Euphronios krater, four vases (namely, a Laconian kylix, a red-figured Apulian dinos attributed to the Darius painter, a red-figured psykter decorated with horsemen and a red-figured Attic amphora by the Berlin painter), a set of fifteen Hellenistic silver items ${ }^{18}$ and a pyxis. They have been displayed at an exhibition held from December 2007 to March 2008 at the Quirinale Palace in Rome (the residence of the President of the Republic), together with other objects recovered from abroad ${ }^{19}$.

The second, but not secondary, objective of the agreement is to promote cultural cooperation between the parties. In exchange for the Euphronios krater, "to make possible the continued presence in the galleries of the Museum of cultural assets of equal beauty and historical and cultural significance", the Ministry agrees to make four-year loans to the Metropolitan Museum of archaeological objects of equivalent beauty and historical and artistic significance selected from a list of twelve artefacts specified in the agreement (Art. 4, para. 1). In exchange for the transfer of the four above mentioned vases, the Ministry agrees to "Ioan a first-quality Laconian artefact to the Museum for a period of four years and renewable thereafter" (Art. 3, para. 2). In exchange for the Hellenistic silvers, the Ministry agrees to make to the Metropolitan Museum Ioans of cultural properties "of equal beauty and historical and artistic significance $<\ldots>$ on an agreed, continuing and rotating sequential basis" (Art. 5, para. 3) ${ }^{20}$. Throughout the forty-year duration of the agreement (Art. 8, para. 1), the mutual co-operation extends to excavations, loans and restorations of cultural objects (Art. 7$)^{21}$.

After its return to Italy as a consequence of the 2006 agreement between the Ministry and the Metropolitan Museum, the Euphronios krater is now exhibited at the Museo Nazionale Etrusco di Villa Giulia in Rome. But would the agreement have been concluded, if a car accident had not occurred? The other agreements have paved the way for the restitution of several unique cultural properties, as the following instances show.

Under the agreement concluded in $\mathbf{2 0 0 6}$ with the Museum of Fine Arts of Boston, the Ministry achieved the restitution of thirteen items, including the marble statue of Vibia Sabina, wife of the Roman emperor Hadrian ${ }^{22}$, and several vases.

18 The fifteen refined items of gilded silver, called Morgantina Silvers, are the most important set of jeweller's art coming from Hellenistic Sicily. They were illegally excavated after 1978 from the archaeological site of Morgantina, an ancient city destroyed by the Romans in $211 \mathrm{~B}$. C. They were bought by the Museum for 3000000 US \$. After the return, they are now exhibited at the Museo Archeologico Regionale of Aidone.

19 See the catalogue of the exhibition: Nostoi - Capolavori ritrovati, 2007. Nostoi means "returns" in Greek.

20 "The Museum shall arrange and bear the costs of packing, insurance and shipment of the requested and loaned items for transit to and from Italy" (Art. 6, para. 4).

21 According to A.K. Briggs "this unprecedented resolution to a decades-old international property dispute has the potential to foster a new spirit of cooperation between museums and source nations, spawn stricter museum acquisition and loan policies, reduce the demand for illicit cultural property, and permanently alter the balance of power in the international cultural property debate" (Briggs A. K. Consequences of the Met-Italy Accord for the International Restitution of Cultural Property // Chicago Journal of International Law. 2007. No. 7 (2). P. 623).

22 See: Polvoledo E. Returning Stolen Art: No Easy Answers // The New York Times. 27 October 2007. P.B13. Available at: https://www.nytimes.com/2007/10/27/arts/design/27ethi.html (accessed: 16.12.2020). According to a joint press communiqué of 28 September 2008, "the agreement includes the creation of a partnership in which the Italian government will loan significant works from Italy to the MFA's displays and special exhibitions program, and establishes a process by which the MFA and Italy will exchange information with respect to the Museum's future acquisitions of Italian antiquities. The partnership 
Under the agreement concluded in 2007 with the John Paul Getty Museum of Los Angeles, the Ministry achieved the restitution of the Venus of Morgantina (a statue of 2,20 m, with head and limbs in marble and body in limestone, illegally excavated in Morgantina ${ }^{23}$ and exported after having been cut in three pieces, paid by the Museum 18000000 US $\$$ ), the Trapezophoros (a support for ritual table that represents two griffons attacking a hind, illegally excavated nearby Ascoli Satriano, paid by the Museum 5500000 US \$) ${ }^{24}$, as well as several vases;

Under the agreements concluded with the Princeton University Art Museum (2007) ${ }^{25}$, the Cleveland Museum of Art (2008) and the Dallas Museum of Art, the Ministry achieved the restitution of respectively eight, fourteen and six cultural properties.

Other cultural properties illegally exported abroad are claimed or might be claimed by Italy. Some of the claims relate to properties that were not included in the above mentioned agreements with American museums, such as the bronze statues of the Victorious Youth (or Athlete), attributed to Lysippus and held by the John Paul Getty Museum²6, and the Cleveland Apollo, attributed to Praxiteles and held by the Cleveland Museum of Art.

\section{An evolutionary trend in present customary international law}

The question of restitution of removed cultural properties to which the treaties in force do not apply for chronological or other reasons is far from being settled under customary international law. While it is not possible to elaborate here on the matter ${ }^{27}$, it seems that an evolutionary trend is developing in present customary international law according to which claims relating to movements of cultural properties should be addressed in order to achieve an equitable solution, taking into account all the relevant circumstances, such as, inter alia:

- the factors surrounding the removal of the cultural property from the State of origin, in particular the legality of the removal under the law of the State of origin or the substantive injustice of the removal;

- the importance of the cultural property for the State of origin, including its emblematic character;

- the harm to the integrity of the cultural context from which the cultural property was removed;

- the amount of time since the cultural property was removed from the State of origin;

- the appreciation for and the care used to preserve the cultural property in the State of destination;

also envisages collaboration in the areas of scholarship, conservation, archaeological investigation and exhibition planning". The statue is now exhibited at the archaeological site of Villa Adriana in Tivoli.

${ }^{23}$ For other cultural properties found in Morgantina see note 18 above.

24 The Venus of Morgantina is now exhibited at the Museo Regionale Archeologico of Aidone, the Trapezophoros at the Museo Civico-Diocesano of Ascoli Satriano. The picture of Mr. Medici next to the Trapezophoros at the John Paul Getty Museum was found in the already mentioned warehouse at the Geneva airport. In 2012 the museum returned to Italy also several marble fragments that belonged to the same tomb from which the Trapezophoros had been illegally excavated.

25 See: Polvoledo E. Princeton to Return Disputed Art to Italy. P. B7.

26 The statue was found on the seabed of the Adriatic Sea. It was clandestinely imported in Italy and then illegally exported abroad. See: Lanciotti $A$. The Dilemma of the Right to Ownership of Underwater Cultural Heritage: The Case of the "Getty Bronze" // Cultural Heritage, Cultural Rights, Cultural Diversity New Developments in International Law / eds S. Borelli, F. Lenzerini. Leiden: Brill, 2012. P. 301; Scovazzi T. Un atleta non ancora giunto a destinazione // Rivista di Diritto Internazionale. 2019. No. 102. P. 511.

27 Some elaboration can be found in Scovazzi T. Diviser c'est Détruire: Ethical Principles and Legal Rules in the Field of Return of Cultural Property // Rivista di Diritto Internazionale. 2011. No. 94 (2). P. 341. 
- the State of origin's commitment to care for the preservation of the cultural property if it is returned to it.

In this regard, the participants to the International Conference of Experts in the Return of Cultural Property, held in Seoul on 16 and 17 October 2012, recommended, inter alia, that

States discuss cases relating to the return of cultural objects not governed by international legal instruments, seeking equitable solutions taking into account all the relevant and specific circumstances, such as integrity of the cultural context, significance of the object for the States concerned, ethical propriety of its removal, treatment of the object by the present possessors, and the State's of origin commitment to security and care of the objects $\langle\ldots\rangle$

States, in attempting to reach equitable solutions, consider means of co-operation with other States, entities and individuals through cultural policy in general, including loans, temporary exhibitions, joint excavation activities, research, and restoration.

The Operational Guidelines for the Implementation of the Convention on the Means of Prohibiting and Preventing the Illicit Import, Export and Transfer of Ownership of Cultural Properties (Paris, 1970), adopted by consensus on $18^{\text {th }}$ May 2015 by the Meeting of States Parties to the convention ${ }^{28}$, provide as follows:

For items of illegally exported, illegally removed or stolen cultural property imported into another State Party before the entry into force of the Convention for any of the States Parties concerned, States Parties are encouraged to find a mutually acceptable agreement which is in accordance with the spirit and the principles of the Convention, taking into account all the relevant circumstances $<\ldots>$ (Op. Guid. 103).

The agreements between the Italian Ministry of Cultural Properties and Activities and the American museums go in the direction of settling disputes on the return of cultural properties in order to reach an equitable solution taking into account all the relevant circumstances. This objective should govern the relationship between the States of origin and the States of destination of cultural properties and should also be shared, if this is the case, also by non-state entities concerned. Non-adversarial procedures, such as negotiation, mediation or conciliation, should be put in place to achieve the objective.

\section{References}

Briggs, Aaron Kyle. 2007. Consequences of the Met-Italy Accord for the International Restitution of Cultural Property. Chicago Journal of International Law 7 (2): 623-653.

Felch, Jason, Frammolino, Ralph. 2011. Chasing Aphrodite - The Hunt for Looted Antiquities at the Worlds' Richest Museum. Boston, Houghton Mifflin Harcourt.

Fiorilli, Maurizio. 2010. Cultural Properties and International Agreements. International Meeting on IIlicit Traffic of Cultural Property, ed. by Jeannette Papadopoulos, Ministero per I Beni e le Attività Culturali: 161-165. Roma, Gangemi Editore.

Lanciotti, Alessandra. 2012. The Dilemma of the Right to Ownership of Underwater Cultural Heritage: The Case of the "Getty Bronze". Cultural Heritage, Cultural Rights, Cultural Diversity - New Developments in International Law, eds Silvia Borelli, Federico Lenzerini: 301-326. Leiden, Brill. Meyer, Karl Ernest. 1973. The Plundered Past. New York, Arts Book Society.

Polvoledo, Elisabetta. 2007. Returning Stolen Art: No Easy Answers. The New York Times 27 October 2007. Available at: https://www.nytimes.com/2007/10/27/arts/design/27ethi.html (accessed: 16.12.2020).

28 See: Scovazzi T., Ferri P. G. Recent Developments in the Fight against the Illicit Export of Archaeological Objects: the Operational Guidelines to the 1970 UNESCO Convention // Art Antiquity and Law. 2015. No. 20 (3). P. 195. 
Rizzo, Maria Antonietta. 1995. Gli scavi clandestini a Cerveteri. Ministero per I Beni Culturale Ambientali. Bollettino d'Arte 89-90: Annex.

Scovazzi, Tullio, Ferri, Paolo Giorgio. 2015. Recent Developments in the Fight against the Illicit Export of Archaeological Objects: the Operational Guidelines to the 1970 UNESCO Convention. Art Antiquity and Law 20 (3): 195-227/

Scovazzi, Tullio. 2011. Diviser c'est Détruire: Ethical Principles and Legal Rules in the Field of Return of Cultural Property. Rivista di Diritto Internazionale 94 (2): 341-395.

Scovazzi, Tullio. 2014. Analisi e significato della pratica italiana. La restituzione dei beni culturali rimossi con particolare riguardo alla pratica italiana, ed. by Tullio Scovazzi. Milan, Giuffre Editore.

Scovazzi, Tullio. 2019. Un atleta non ancora giunto a destinazione. Rivista di Diritto Internazionale 102: 511-518.

Watson, Peter, Todeschini, Cecilia. 2006. The Medici Conspiracy - The Illicit Journey of Looted Antiquities from Italy's Tomb Raiders to the World's Greatest Museums. New York, Public Affairs.

Received: June 29, 2020

Accepted: December 23, 2020

\section{Реституция незаконно вывезенных культурных ценностей: недавние итальянские кейсы}

\section{Т. Сковацци}

Для цитирования: Scovazzi, Tullio. The Restitution of illicitly exported cultural properties: Recent Italian cases // Правоведение. 2020. T. 64, № 1. С. 156-163.

https://doi.org/10.21638/spbu25.2020.112

Вопрос о реституции перемещенных культурных ценностей, на которые действующие договоры не распространяются по хронологическим или иным причинам, далеко не решен в рамках обычного международного права. В современном международном обычном праве наблюдается тенденция, согласно которой претензии по поводу перемещения культурных ценностей должны рассматриваться для достижения справедливого решения с учетом всех сопутствующих обстоятельств. Эти обстоятельства включают: факторы, связанные с изъятием культурного достояния из государства их происхождения, в частности законность изъятия в соответствии с законодательством государства происхождения или материальную несправедливость изъятия; важность культурного достояния для государства происхождения, в том числе его символический характер; ущерб целостности культурного контекста, из которого было изъято культурное достояние; количество времени, прошедшего с момента изъятия культурного достояния из государства происхождения; признание и забота, проявляемые для сохранения культурных ценностей в государстве назначения; обязательство государства происхождения заботиться о сохранении культурных ценностей, если они будут возвращены ему. Соглашения между итальянским Министерством культурных ценностей и культурной деятельности и американскими музеями направлены на урегулирование споров о возвращении культурных ценностей для достижения справедливого решения с учетом всех сопутствующих обстоятельств. Достижение такого решения должно стать основой отношений между государствами происхождения и государствами назначения культурных ценностей; данную цель должны разделять и заинтересованные негосударственные образования. При этом следует применять неконкурентные процедуры, такие как переговоры, посредничество или примирение.

Ключевые слова: реституция, изъятые культурные ценности, международное обычное право, примирительные процедуры, медиация, мировое соглашение, нелегально экспортированные культурные ценности, итальянские кейсы.

Статья поступила в редакцию: 29 июня 2020 г. Рекомендована в печать: 23 декабря 2020 г.

Сковацци Туллио - профессор международного права, Университет Милана-Бикокка, Италия, 20126, Милан, пл. дель Атенео Нуово, 1; tullio.scovazzi@unimib.it 